ESSAY

\title{
An overview of the listing process under the California Endangered Species Act
}

\author{
PAUL S. WEILAND ${ }^{1 *}$, STEPHANIE N. CLARK ${ }^{1}$, AND \\ ASHLEY J. REMILLARD ${ }^{2}$ \\ ${ }^{1}$ Nossaman LLP, 18101 Von Karman Ave., Suite 1800, Irvine, CA 92618, USA \\ ${ }^{2}$ Agility Fuel Solutions, 3335 Susan St., Suite 100, Costa Mesa, CA 92626, USA \\ *Corresponding Author: pweiland@nossaman.com
}

The California Endangered Species Act (CESA) is one of the most important legal tools available to the Fish and Game Commission and Department of Fish and Wildlife to protect the State's wildlife resources. The listing process, together with the prohibitions in section 2080 of the Fish and Game Code, are the law's regulatory teeth. At the same time, because any interested person can petition to list a species, the listing process invites citizen participation in the regulatory scheme. Listing decisions can be the difference between persistence and extinction of a species. They can also cause severe economic disruption and, for this reason, should in our view be made with due deliberation and based on the best available scientific information. Here we describe the complex roadmap that petitions must navigate and that is intended to assure that only native species that need protection get it.

Key words: CESA, endangered species, listing

At the heart of the California Endangered Species Act (CESA) is a process whereby species are listed as endangered or threatened and such species are afforded broad protections. This process - which both provides for the listing of species, as well as prohibits conduct that could harm the species - is intended to halt the decline of species at risk of extinction and, ultimately, contribute to the conservation of such species so that they may be removed from the list of endangered and threatened species. Below we provide an overview of this process, including a description of the procedures whereby the Fish and Game Commission (Commission) considers whether to list a species, and a discussion of the role of the Department of Fish and Wildlife (Department) in the listing process.

Section 2070 of the Fish and Game Code provides that "[t]he commission shall establish a list of endangered species and a list of threatened species." CESA defines an endangered species as "a native species or subspecies of a bird, mammal, fish, amphibian, reptile, or plant which is in serious danger of becoming extinct throughout all, or a significant portion, of its range due to one or more causes, including loss of habitat, change in habitat, overexploitation, predation, competition, or disease" (Fish \& G. Code $\S 2062$ ). It defines a 
threatened species as "a native species or subspecies of a bird, mammal, fish, amphibian, reptile, or plant that, although not presently threatened with extinction, is likely to become an endangered species in the foreseeable future in the absence of the special protection and management efforts required by this chapter" (Fish \& G. Code § 2067).

Section 2071 requires the Commission to adopt guidelines so "an interested person may petition the commission to add a species to, or to remove a species from either the list of endangered or the list of threatened species." Those guidelines are set out in Section 670.1, Title 14, of the California Code of Regulations. In the alternative, section 2072.7 of the Fish and Game Code provides that the Department may "recommend to the commission that it add a species to, or remove a species from, either the list of endangered species or the list of threatened species."

\section{THE SCOPE OF CESA}

CESA extends to "native species or subspecies of a bird, mammal, fish, amphibian, reptile, or plant" (Fish \& G. Code $\S \S 2062$ (definition of endangered species), 2067 (definition of threatened species), 2068 (definition of candidate species)). By its plain language, it does not extend to other forms of life though the argument has been made that the broad definition of "fish" in the Fish and Game Code expands the protections CESA provides beyond the plain meaning of fish to include all invertebrates. In 1998, Assembly member Keith Olberg requested an opinion of the Attorney General regarding the eligibility of insects for listing under CESA (Cal. Op. Atty. Gen. 98-105). In response, the Attorney General opined: "Insects are ineligible for listing as a threatened or endangered species under the California Endangered Species Act" (Id.). He further explained: "These definitions limit the application of CESA to birds, mammals, fish, amphibians, reptiles, and plants. Insects do not fall within any of these categories" (Id.).

The Attorney General's opinion reaffirmed an earlier decision by the Office of Administrative Law that insects are not subject to listing under CESA. In 1980, certain parties sought to list the Smith's blue butterfly (Euphilotes enoptes smithi), and the Lange's Metalmark butterfly (Apodemia mormo langei) under CESA. The Commission voted to list both butterflies, and the decision went to the Office of Administrative Law. As authority for its position that the butterflies could be listed, the Commission reasoned that (1) the definitions of endangered and threatened species expressly include fish, (2) section 45 of the Fish and Game Code expressly defines fish to include invertebrates, (3) insects are invertebrates, (4) insects are therefore fish, and, (5) insects can be listed. The Office of Administrative Law determined that the Commission acted outside its authority in listing the two butterflies, concluding that, despite the Commission's arguments, insects are not fish (Price 1981). Thereafter, the Commission rescinded its prior action.

While not binding, the U.S. Fish and Wildlife Service's long-held position - articulated in Federal Register notices regarding various insect species and citing communications with the California Department of Fish and Wildlife for support - is consistent with that taken by the California Attorney General's Office and the State's Office of Administrative Law. At least as far back as 1997, a Federal Register notice regarding the Callippe Silverspot butterfly (Speyeria callippe callippe) and Behren's Silverspot butterfly (Speyeria zerene behrensii) stated "The California Endangered Species Act (CESA) does not provide protection to insects (sections 2062, 2067 and 2068, Fish and Game Code)" (USFWS 1997). More recently, the U.S. Fish and Wildlife Service affirmed its prior position, for example, stating in 
2011, in a notice regarding the Casey's June beetle (Dinacoma caseyi), that "The California Endangered Species Act (CESA) provides protections for many species of plants, animals, and some invertebrate species. However, insect species, such as Casey's June beetle, are not afforded protection under CESA" (USFWS 2011).

In 2018 , the Xerces Society and others filed a petition to list four subspecies of bumble bee as endangered under CESA. In response, the Department issued a 90-day evaluation recommending the Commission accept the petition, and the Commission voted to accept the petition, thereby determining that listing the species may be warranted. Soon thereafter, a number of organizations representing the farming community filed a petition in Superior Court challenging the Commission's action on the grounds that listing the subspecies of bumble bees is precluded as a matter of law. The court decided in favor of petitioners, holding "the absence of authority to list insects under CESA, either as fish or otherwise, is clear" (Almond Alliance et al. v. Cal. Fish \& Game Com. (13 Nov 2020, Super. Ct. Sacramento County No. 34-2019-80003216)). The Commission appealed the trial court's decision, and that appeal is pending.

\section{THE DEFINITION OF SPECIES}

Neither CESA nor the Fish and Game Code generally define the term "species." But the definitions of endangered and threated species (Fish \& G. Code $\S \S 2062,2067$ ) both expressly encompass "native species or subspecies." The species concept has a rich history in the biological sciences. Species are commonly defined as groups of individuals that are morphologically or genetically distinct from other groups of individuals or as groups of individuals that can breed among themselves and that do not breed with other groups (Primack 2006). Over time, within the scientific community and beyond, there have been strident disagreements regarding the application of these definitions, in part because of their legal and policy implications.

The subspecies concept is both biological and legal. As a result, it has been the subject of greater controversy than the species concept. For example, after the Commission listed one population of Coho Salmon (Oncorhynchus kisutch) on the northern California coast as a threatened species, and another population of Coho Salmon on the central coast as an endangered species, the California Forestry Association challenged the listing decisions. The trial court upheld the Commission's decisions, and the Court of Appeal affirmed.

The Court of Appeal began by noting that the proper interpretation of the term "species or subspecies" in the statute is a question of law that the courts review de novo (California Forestry Assn. v. California Fish \& Game Commission (2007) 156 Cal. App. 4th 1535,1544$)$. It went on to explain that the Commission and Department determined to list the two populations of Coho Salmon to maintain the diversity of the species in order to contribute to its preservation (Id. at 1546-1547). Ultimately, the Court of Appeal deferred to the Commission's decision to list two evolutionarily significant units of Coho Salmon, noting this is consistent with the liberal construction it accords laws such as CESA (Id. at 1548-49). The decision signals the willingness of the judiciary to defer to the Commission and Department to determine when a listing of a population of a species (but not the entirety of the species) is appropriate.

Some commentators have objected to the Court of Appeal decision. Schiff and Thompson (2010) argue that the court erred by reading the statute too expansively, so as to extend it to include evolutionarily significant units ESU). They point out that whereas 
the federal Endangered Species Act includes species, subspecies, and distinct population segments (DPS), CESA only includes species and subspecies. They also note that the two Acts are similar in many respects, and argue that the decision of the California legislature not to include the term "distinct population segments" in the definitions of endangered and threatened species is strong evidence that CESA does not extend to DPSs or ESUs. But for the time being, the liberal construction of the statute adopted by the Court of Appeal stands. The Court of Appeal, in a recent case concerning the Coho Salmon confirmed that, similar to how a population can only be listed if it qualifies as a species, subspecies, or ESU, a population can only be delisted if it (1) can be defined as a separate species, subspecies, or ESU, and (2) if the determination can be made that the separate species, subspecies, or ESU is not endangered (Central Coast Forest Assn. v. Fish and Game Commission (2017) 18 Cal.App.5th 1191, 1239-1240).

The Commission has, in several instances since the Coho Salmon decision was upheld, listed subspecies. For example, the Commission voted in 2016 to list the Southern Sierra Nevada Evolutionarily Significant Unit of the fisher (Pekania pennanti) as a threatened species (Fish and Game Commission 2016). Similarly, the Commission voted in 2020 to list the Southwest/South Coast, West/Central Coast, and East/Southern Sierra clades of the foothill yellow-legged frog (Rana boylii) as endangered and the Northeast/Northern Sierra and Feather River clades of the species as threatened (Fish and Game Commission 2020a). Also, in 2020, the Commission voted to the make the Southern California/Central Coast ESU of mountain lions (Puma concolor) a candidate species (Fish and Game Commission 2020b). The decision was controversial and could lead to litigation that addresses the definition of species (Sahagun 2020).

In a case decided in early 2019, a trial court addressed the other prong of the "native species or subspecies" requirement in CESA, namely whether a species is native to California (Cal. Cattlemen's Assn. v. Cal. Fish \& Game Commission (Jan. 28, 2019, Super. Ct. San Diego County, No. 37-2017-00003866-CU-MC-CTL)). At issue in the case was the Commission's decision to list the gray wolf (Canis lupus).

According to the administrative record, gray wolves historically inhabited most of the United States, including much of California, until they were extirpated from California almost 100 years ago. In December 2011, a lone gray wolf known as OR-7 dispersed from northeastern Oregon's gray wolf population and was observed crossing the Oregon-California border in both directions, multiple times. Shortly thereafter, in 2012, the Center for Biological Diversity and others submitted a petition to list the gray wolf to the Commission. In its 12-month review of the petition, the Department noted that the presence of OR-7 in California in late 2011 was the first wolf sighting in California since extirpation in the 1920s. It went on to explain that there has been no breeding population of gray wolves in California for many decades and that, as a consequence, the Department considered information on the status of the species from other states when undertaking its review. Ultimately, the Department recommended against listing.

The Commission sided with petitioners and against the Department, opting to list the gray wolf as endangered. Agriculture and ranching groups challenged the Commission's listing decision on the grounds that the gray wolf did not meet the criteria for listing set forth in section 2062 (Fish \& G. Code $\S$ 2062). Specifically, the groups argued that the listing was improperly based on the presence of a non-native subspecies of gray wolf, that the intermittent presence of a single wolf did not warrant a finding that the gray wolf's 
range included California, and that the gray wolf was not at risk of extinction throughout its entire range, which extended beyond California. The court disagreed, holding that section 2062 of the Fish and Game Code permits the listing of native species in addition to native subspecies, and that furthermore, the Commission's scientific finding that OR-7 possessed some genetic markers of a native California subspecies (Canis lupus nubilus) was entitled to deference. The court also held that the Commission could reasonably find that listing was necessary to protect the gray wolf from extinction in California based on the intermittent presence of OR-7 and other wolves, along with the possibility that a breeding population might be established in California in the foreseeable future.

While this decision is notable, particularly because the gray wolf is an iconic species in the history of the western United States, its implications for future listing decisions are limited, as the fact that the gray wolf was native to and present in California in the relatively recent past was not in dispute.

\section{THE PETITION}

The listing process commences with the submission of a petition to the Commission. The significant milestones in the process are illustrated in Figure 1. Petitions must be submitted on an authorized petition form (Cal. Code Regs., tit. 14, $\S 670.1$ (a)). To be accepted, a petition must include sufficient scientific information that the petitioned action may be warranted (Fish \& G. Code $\S 2072.3$ ). The Fish and Game Code provides that it must include information regarding "the population trend, range, distribution, abundance, and life history of a species, the factors affecting the ability of the population to survive and reproduce, the degree and immediacy of the threat, the impact of existing management efforts, suggestions for future management, and the availability and sources of information," and "the kind of habitat necessary for species survival, a detailed distribution map, and any other factors that the petitioner deems relevant" (Id.).

In response to a petition to list the western Joshua tree (Yucca brevifolia brevifolia), the Commission recently found that the petition provides sufficient information to indicate that the petitioned action may be warranted, thereby making the species a candidate for listing. The Commission's decision is notable because the petition did not include information on "population trend" and "abundance," which arguably must be included in a petition under section 2072.3. The petition stated that "a reliable estimate of Joshua tree population size is not available," and that "no range-wide population trends have been documented" (Center for Biological Diversity 2019). Further, the Department's 90-day evaluation affirmed "[ $\mathrm{t}]$ he Petition does not present an estimate of western Joshua tree population size, nor does it provide evidence of a range-wide population trend" (Department of Fish and Wildlife 2020). Nonetheless, the Commission concurred with the Center for Biological Diversity and Department that climate change, combined with other factors including habitat loss, provide grounds to designate the species a candidate for listing. The decision is being challenged in Superior Court and the outcome of the lawsuit may provide greater clarity regarding the extent to which petitioners are required to provide information on each of the factors identified in section 2072.3.

Commission staff must review a petition for completeness. An incomplete petition shall be returned to the petitioner by Commission staff within 10 days of receipt (Cal. Code Regs., tit. 14, $\S 670.1(\mathrm{~b})$ ). If the petition is deemed complete, the Commission is required to 
refer it to the Department (Fish \& G. Code $§ 2073$ ). Commission staff must submit notice of complete petitions to the Office of Administrative Law for publication in the California Regulatory Notice Register, at the time the petition is transmitted to the Department for evaluation (Fish \& G. Code $\S 2073.3$; Cal. Code Regs., tit. 14, $\S$ 670.1(c)). Such notice must

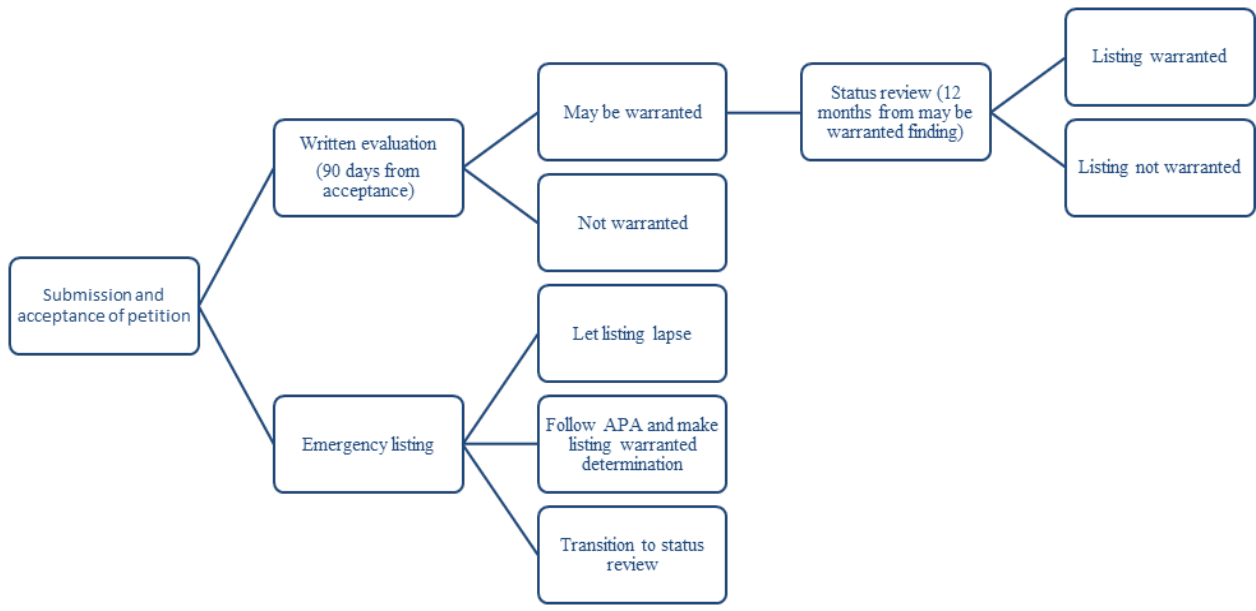

Figure 1. Significant milestones in the CESA listing process.

include the date and location of the Commission meeting at which the petition is formally scheduled for receipt. Commission staff has treated this review as largely perfunctory.

\section{THE DEPARTMENT'S WRITTEN EVALUATION}

Within 90 days of receipt of the petition, the Department is required to submit a written evaluation of the petition to the Commission (Fish \& G. Code $\S 2073.5(\mathrm{a})$ ). The Department's Wildlife Branch and Habitat Conservation Planning Branch staff coordinate evaluation of petitions. The evaluation of whether or not the petition is complete is to be based on the petition and other relevant information the Department possesses or receives (Id). It must address each of the following petition components.
(A) population trend;
(B) range;
(C) distribution;
(D) abundance;
(E) life history;
(F) kind of habitat necessary for survival;
(G) factors affecting the ability to survive and reproduce;
(H) degree and immediacy of threat;
(I) impact of existing management efforts;
(J) suggestions for future management;
(K) availability and sources of information; and
(L) a detailed distribution map.

(Cal Code Regs., tit. 14, § 670.1(d)(1)). In addition, it must be accompanied by a recommendation that the petition be rejected or accepted and considered (Fish \& G. Code 
$\S 2073.5(a))$. Upon a request by the Director of the Department, the Commission may grant the Department an extension of up to 30 days to complete the evaluation (Id. § 2073.5(b)).

\section{CANDIDACY}

After the Department releases its written evaluation, the Commission must schedule both the petition and written evaluation for consideration at the Commission's next available meeting, but not sooner than 30 days after receipt of the petition and written evaluation (Fish $\&$ G. Code $\S 2074)$. At the meeting, the Commission is obliged to accept written materials and oral testimony (Id. § 2074.2(a)). After the conclusion of testimony, the Commission may either close or leave open the hearing (Id. § 2074.2(a), (d)). If the Commission closes the hearing, it may either continue the meeting on the petition or make a finding (Id. $\S$ 2074.2(d), (e)).

The Commission may make one of two findings with respect to a petition to list: (1) it may find that the petition does not provide sufficient information to indicate that the petitioned action may be warranted and reject the petition or (2) it may find that the petition provides sufficient information to indicate that the petitioned action may be warranted and publish a notice of finding that the petition is accepted for consideration (Fish \& G. Code $\S 2074.2(\mathrm{e})$ ). In making the decision whether a listing may be warranted, the Commission must weigh the evidence for and against candidate listing and decide essentially a question of fact in the process (Natural Resources Defense Council v. Fish \& Game Com. (1994) 28 Cal. App. 4th 1104, 1116). As the Third District Court of Appeal explained, "the section 2074.2 phrase 'petition provides sufficient information to indicate that the petitioned action may be warranted' means that amount of information, when considered in light of the Department's written report and the comments received, that would lead a reasonable person to conclude there is a substantial possibility the requested listing could occur" (Id. at 1125; see also Center for Biological Diversity v. Fish and Game Commission (2008) 166 Cal. App. 4th 597, 609-10). In both cases referenced above, the Court of Appeal overturned the determination of the Commission that the petition to list was not warranted. In contrast, there are no reported cases in which a party has successfully challenged a Commission determination that a petition to list is warranted based on the information included in the petition. That said, the Commission has on a number of occasions determined that a petition to list is not warranted.

If the Commission finds that the petition does not provide sufficient information to indicate that the petitioned action may be warranted, it must publish a notice of its finding that the petition is rejected in the California Regulatory Notice Register (Cal. Code Regs., tit. $14, \S 670.1(\mathrm{e})(1))$. If the Commission accepts a petition that recommends listing the species as endangered or threatened, the Commission shall include in its notice of finding that the petitioned species is a candidate species (Fish \& G. Code $\S 2074.2(\mathrm{e})(2)$ ). The Commission must publish the notice in the California Regulatory Notice Register (Cal. Code Regs., tit. $14, \S 670.1(\mathrm{e})(2))$.

\section{STATUS REVIEW}

If a petition is accepted, the Commission is required to make reasonable attempts to notify affected and interested parties and to solicit data and comments on the petitioned action from as many persons as is practicable (Fish \& G. Code § 2074.4). In addition, the 
Department is required to commence a status review of the species that is the focus of the petition (Id. § 2074.6). Within 12 months of the date of publication of a notice of acceptance of a petition for consideration, the Department is required to produce a report (or status review) that indicates whether the petitioned action is warranted, includes a preliminary identification of the habitat that may be essential to the continued existence of the species, and recommends management activities and other recommendations for recovery of the species (Ibid). The Department's Wildlife Branch or Habitat Conservation Planning Branch staff coordinate preparation of the status review.

The status review must be peer reviewed and based upon the best scientific information available $(I d$.). Interested parties may recommend reviewers to the Department, but the process for selecting reviewers is in the Department's sole discretion. The Department does not compensate persons who conduct peer reviews. As a practical matter, it can be difficult to attract experts in the field to the peer review process because it is time consuming and does not involve any remuneration. Moreover, individuals that are willing to participate in the peer review process may have an interest in the outcome of the petitioned action, which makes finding neutral peer review participants challenging.

Where the Department fails to include proper peer review in its status report, it cannot serve as the basis for the Commission's decision on a petition for listing (Center for Biological Diversity v. Cal. Fish \& Game Com., No. CGC-10-505205 (San Francisco Sup. Ct. 23 July 2012)). The Superior Court's decision underscores the importance of peer review in the CESA listing process and the weight that CESA places on relying on credible science (or the best available scientific information) in making listing decisions.

Prior to releasing the final status review, the Department must evaluate and respond in writing to the independent peer review and amend the draft status review report as appropriate (Id.). Commission regulations define peer review as "the analysis of a scientific report by persons of the scientific/academic community commonly acknowledged to be experts on the subject under consideration, possessing the knowledge and expertise to critique the scientific validity of the report" (Cal. Code Regs., tit. 14, § 670.1(f)(2)). Both the draft and final status reviews are part of the administrative record and included in the materials provided to the Commission before it makes a final listing decision.

Commission regulations also provide that interested parties who wish to submit a detailed written scientific report to the Commission must do so not later than the time the Department submits its report and that reports received thereafter may not be considered (Cal. Code Regs., tit. 14, § 670.1(h)(1)). They further provide that such parties may seek independent and competent peer review of the report prior to submission and include all comments from the reviewers with the report to verify that peer review has been solicited $(I d . \S 670.1(\mathrm{~h})(2))$. In practice, interested parties routinely submit comments on the Department status review but rarely prepare an alternative status review of the species.

\section{THE FINAL LISTING DECISION}

The Commission is required to schedule the petition for final consideration at its next meeting after receiving the Department's final status review (Fish \& G. Code § 2075; Cal. Code Regs., tit. 14, §670.1 (g)(1)). At the meeting, the Commission is obliged to accept written materials and oral testimony (Fish \& G. Code $\S 2075.5(\mathrm{a})$ ). After the conclusion of testimony, the Commission may either close or leave open the hearing (Id. § 2075.5(a), (d)). After the hearing is closed, the administrative record for the Commission's decision 
is closed (Id. $\S 2075.5(\mathrm{~b}))$. The administrative record may only be reopened if there is a change in state or federal law or regulation that has a direct and significant impact on the Commission's determination as to whether the petitioned action is warranted or if the Commission determines that it requires further information to evaluate whether the petitioned action is warranted (Id. § 2075.5(c)).

The Commission may make one of two findings with respect to a petition to list: (1) it may find that the petitioned action is not warranted, in which case the finding shall be entered in the Commission's records and the petitioned species shall be removed from the list of candidate species, (2) that the petitioned action is not warranted but listing the species at a different level than petitioned is warranted (i.e., petition to list as endangered is not warranted but listing as threatened is), or (3) it may find that the petitioned action is warranted, in which case the Commission shall publish a notice of that finding and a notice of proposed rulemaking pursuant to the Administrative Procedure Act, to add the species to the list of endangered species or the list of threatened species (Fish \& G. Code $\S 2075.5(\mathrm{e})$ ). The typical practice of the Commission is to vote on the adoption of findings at a subsequent meeting in order to allow staff to prepare written findings consistent with the action taken. Where the Commission is changing the status of a species, it must submit the change in status to the Office of Administrative Law for filing with the Secretary of State and publication in the California Code of Regulations (Id. § 2075.5(e)(2)).

One consequence of the fact that the Commission votes on whether the action is warranted at one meeting then votes on adoption of findings at a subsequent meeting is that the Commission has an opportunity to re-visit is prior decision at the subsequent meeting. By and large, this is irrelevant because the same Commissioners who vote on whether the action is warranted vote at the next meeting on the adoption of findings. But if Commissioners are absent from a meeting or if a Commissioner resigns his or her post or is replaced, then it is possible such a change in the voting members will lead to a circumstance where the vote on adoption of findings becomes a vote on reconsideration. There is no evidence this is what the Legislature intended. But absent statutory or regulatory clarification that the findings adopted must support the prior determination, there is the possibility of reconsideration.

A petition to delist may be granted on the basis of a determination that the factors that were the basis for listing no longer threaten the continued existence of the species or because the decision to list was in error in light of the available evidence (Central Coast Forest Assn. v. Fish and Game Commission (2017) 2 Cal.5th 594, 604-605; Central Coast Forest Assn. v. Fish and Game Commission (2018) 18 Cal.App.5th 1191, 1204-1205.). In the case referenced above, the California Supreme Court found that a petition that presents new evidence to the Commission regarding the status of an already-listed species must still be reviewed by the Commission in the same way it would review a petition for listing (Central Coast Forest Assn. v. Fish and Game Commission, supra, 2 Cal.5th at p. 606). The California Supreme Court found that a delisting petition that provided new evidence that a population of Coho Salmon should not have been listed as endangered originally was the proper method of challenging the original listing decision (Id.). On remand, the Court of Appeal found that the Commission appropriately determined that the petitioned action of delisting the populations of Coho Salmon south of Punta Gorda (Humboldt County) was not warranted (Central Coast Forest Assn. v. Fish and Game Commission, supra, 18 Cal. App.5th at pp. 1224-1235). This was, in part, because there was neither evidence that those populations of Coho Salmon consisted entirely of hatchery stocks nor evidence that the 
populations south of Punta Gorda were non-native. Thus, the Coho Salmon populations could not be considered ESUs, as is required to either list or delist only a population of a species under CESA.

\section{EMERGENCY LISTING}

The Fish and Game Code authorizes the Commission to adopt a regulation adding a species to the list of endangered species or to the list of threatened species as an emergency regulation if the Commission finds that there is an emergency posing a significant threat to the continued existence of the species (Fish \& G. Code $\S 2076.5$ ). The Commission is required to notify affected or interested persons of the adoption of such an emergency regulation $(I d$.). To date, the only species that the Commission has listed on an emergency basis is the tricolored blackbird (Agelaius tricolor). The Commission listed the tricolored blackbird on an emergency basis in December 2014. The Commission subsequently let the emergency listing lapse, by vote, in June 2015.

The Administrative Procedure Act (Cal. Gov’t Code $\S \S 11340-11365$ ) governs emergency regulations promulgated by state agencies, including emergency listing decisions. Subsection 11346.1(b)(1) states "if a state agency makes a finding that the adoption of a regulation or order of repeal is necessary to address an emergency, the regulation or order of repeal may be adopted as an emergency regulation or order of repeal" (Cal. Gov't Code $\S 11346.1(b)(1))$. Further, Government Code section 11346.1 states as follows: "No regulation, amendment, or order of repeal initially adopted as an emergency regulatory action shall remain in effect more than 180 days unless the adopting agency has complied with Sections 11346.2 to 11347.3 , inclusive, either before adopting an emergency regulation or within the 180-day period." (Id.).

In light of the requirements of the Administrative Procedure Act, the Commission may let an emergency listing rule lapse after 180 days, comply with the requirements set forth in the Administrative Procedure Act then adopt the listing rule on a permanent basis, or elect to follow the traditional listing procedure by requesting a written evaluation from the Department and determining whether the petition provides sufficient information to indicate that the petitioned action may be warranted.

\section{PROTECTIONS AFFORDED LISTED AND CANDIDATE SPECIES}

Once a species is listed under CESA, it is afforded broad protections that are intended to serve the dual purpose of halting the decline of the species, while also contributing to the conservation of the species so that it may ultimately be removed from the list of endangered and threatened species. Specifically, pursuant to Fish and Game Code section 2080, "[n] o person or public agency shall import into this state, export out of this state, or take, possess, purchase, or sell within this state, any species, or any part or product thereof, that the commission determines to be an endangered species or a threatened species, or attempt any of those acts" (Fish \& G. Code $\S 2080$; Cal. Code Regs., tit. 14, § 783.1). The term "take" is defined to mean "[h]unt, pursue, catch, capture, or kill, or attempt to hunt, pursue, catch, capture, or kill" (Fish \& G. Code $\S 86$ ). These acts are prohibited with respect to listed species and candidate species, as candidate species receive the same legal protections afforded to endangered or threatened species (Fish \& G. Code $\S 2085$ ). Penalties for violating the take prohibition range from $\$ 25,000$ to $\$ 50,000$ for each violation, one-year imprisonment, or both fine and imprisonment (Fish \& G. Code § 12008.1). 
The Department may authorize the take of a listed species if certain conditions are met. The following is a non-exhaustive list of take authorizations available under CESA: (1) Through permits or memoranda of understanding, the Department may authorize individuals, public agencies, universities, zoological gardens, and scientific or educational institutions, to import, export, take, or possess any endangered species, threatened species, or candidate species for scientific, educational, or management purposes (Fish \& G. Code $\S 2081(\mathrm{a})$ ); (2) Through incidental take permits, the Department may authorize take that is expected to occur incidental to otherwise lawful activities (Id., § 2081(b)); (3) Through safe harbor agreements, the Department may offer, in exchange for actions that contribute to the recovery of listed species, formal assurances to private landowners that their activities will not be deemed to violate the take prohibition (Id., §§ 2089.2-2089.26); (4) Through a consistency determination, the Department may authorize take of a listed species, provided the species is also listed under the federal Endangered Species Act, take authorization has been obtained pursuant to that Act, and the authorization is consistent with CESA (Id., § 2080.1); (5) Through the Natural Community Conservation Planning program, the Department may authorize take pursuant to comprehensive conservation and management plans (Id., $\S \S$ 2800-2835); and (6) Through voluntary local programs, the Department may authorize farmers and ranchers to take listed species incidental to routine and ongoing agricultural activities (Id., §§ 2086-2089).

The Commission has separate authority under section 2084 of the Fish and Game Code to authorize the taking of any candidate species based on the best available scientific information (Fish \& G. Code $\S 2084$ ). To utilize this authority, the Commission must adopt a regulation either simultaneous with its decision to make a species a candidate for listing or at a subsequent meeting. This is commonly referred to as a 2084 regulation. Historically, the Commission made greater use of this authority under section 2084 than it has in the past 10 years. This decline in the use of its authority is a consequence of a challenge to a 2084 regulation for the black-backed woodpecker (Picoides arcticus) that led to an out-of-court settlement and stipulated dismissal of the lawsuit. (This history is recounted in subsequent litigation between the parties with respect to attorney's fees, Center for Biological Diversity v. Fish \& Game Commission (28 Jan 2014, A137889) [nonpub. opn.].) Since then, the Commission has adopted 2084 regulations for two candidate species: tricolored blackbird and western Joshua tree. In both cases, petitioners and the Department did not oppose the regulations. This could indicate an unwillingness on the part of the Commission to adopt 2084 regulations that are opposed by petitioners, the Department, or both.

\section{CONCLUSION}

CESA, much like its federal counterpart, provides a comprehensive scheme for petitioning, reviewing, listing, and authorizing take of threatened and endangered species. However, unlike its federal counterpart, CESA contemplates a petition process that plays out before two agencies - the Department and the Commission - and relies on a definition of species and subspecies that is arguably narrower than that employed by the federal Endangered Species Act. The latter of these two distinctions may not hold over time as a consequence of the position taken by the Commission and the judiciary in recent years. But when the Commission takes steps that arguably push the limits of its authority - as some argue it has done in recent actions regarding bumble bees and mountain lions - interests groups may be expected to turn to the other branches of government to make their case for or against 
listing. In the coming years, it seems likely that the courts and perhaps even the legislature will play as meaningful a role in the evolution of CESA as the Commission and Department.

\section{LITERATURE CITED}

Almond Alliance et al. v. California Fish and Game Commission (13 Nov 2020, Superior Court Sacramento County No. 34-2019-80003216) [nonpublished opinion].

California Attorney General Opinion 98-105.

California Cattlemen's Association v. California Fish and Game Commission (28 Jan 2019, Superior Court San Diego County No. 37-2017-00003866-CU-MC-CTL) [nonpublished opinion].

California Forestry Association v. California Fish \& Game Commission (2007) 156 Cal. App. 4th 1535.

Central Coast Forest Association v. Fish and Game Commission (2017) 2 Cal.5th 594.

Central Coast Forest Association v. Fish and Game Commission (2018) 18 Cal.App.5th 1191.

Center for Biological Diversity v. Fish and Game Commission (Jan. 28, 2014, A137889)

[nonpublished opinion]

Center for Biological Diversity v. Fish and Game Commission (2008) 166 Cal.App.4th 597.

Center for Biological Diversity v. California Fish and Game Commission (Super. Ct. San Francisco County, 2012, No. CGC-10-505205).

Center for Biological Diversity. 2019. A Petition to List the Western Joshua Tree (Yucca brevifolia) as Threatened under the California Endangered Species Act (CESA).

California Department of Fish and Wildlife (CDFW). 2020. Evaluation of a Petition to List the Western Joshua Tree (Yucca brevifolia) as Threatened under the California Endangered Species Act (CESA).

Fish and Game Commission (FGC). 2016. Notice of Findings: Fisher (Pekania pennanti). Fish and Game Commission (FCG). 2020a. Notice of Findings for Foothill Yellow-Legged Frog (Rana boylii).

Fish and Game Commission (FGC). 2020b. Notice of Findings: Mountain Lion (Puma concolor).

Natural Resources Defense Council v. Fish and Game Commission (1994) 28 Cal. App. 4th 1104.

Primack, R. B. 2006. Essentials of Conservation Biology. Sinauer Associates, Sunderland, MA, USA.

Price, M. E. 1981. California Office of Administrative Law. Report to the Administrative Conference of the United States, Washington, D.C., USA

Sahagun, L. 2020. Southern California mountain lions get temporary endangered species status, Los Angeles Times (16 April 2020).

Schiff, D. M., and J. P. Thompson. 2010. The distinct population segment provision of the Endangered Species Act and the lack thereof in the California Endangered Species Act. Journal of Land Resources and Environmental Law 30:267-294.

U.S. Fish and Wildlife Service (USFWS). 2011. Determination of endangered status for Casey's June beetle and designation of critical habitat; Final Rule, 76. Federal Register 58,954.

U.S. Fish and Wildlife Service (USFWS). 1997. Determination of endangered status for 
the Callippe silverspot butterfly and the Behren's silverspot butterfly and threatened status for the Alameda whipsnake; Final Rule, 62. Federal Register 64,306.

Submitted 18 April 2019

Accepted 17 April 2020

Associate Editor was M. Mantor 